\title{
Recurrent vasculitis in cystic fibrosis
}

\author{
Lareina Wujanto, ${ }^{1}$ Clare Ross² \\ ${ }^{1}$ Dermatology Department, Ealing Hospital, Southall, Middlesex, UK \\ ${ }^{2}$ Department of Respiratory Medicine, Queen Elizabeth II Hospital, Howlands, Middlesex, Hertfordshire, UK
}

Correspondence to Lareina Wujanto, reinawujanto@gmail.com

\section{Summary}

A 22-year-old man presented with recurrent palpable purpuric rash. His clubbing relates to underlying cystic fibrosis (CF) and his rash was identified as CF-related vasculitis, a rare extrapulmonary manifestation of the disease. It occurs predominantly on the lower limbs, mainly over the dorsa of the feet, ankles and tibial surfaces. The rash occurred while the patient had an infective exacerbation of CF (IECF), however, there had also been previous occurrences without worsening of his pulmonary symptoms, to which the rash remitted spontaneously. The patient responded well to immunosuppression, which was given on this admission due to worsening of his CF-related vasculitis. He died 18 months within the onset of his initial rash.

\section{BACKGROUND}

We have submitted this case report for two reasons. First, this is an unusual presentation of cystic fibrosis (CF), the commonest recessive genetic disorder affecting the Caucasian population. ${ }^{1}$ Most patients have severe pulmonary disease and the occurrence of vasculitis is often associated with a poor prognosis. ${ }^{2}$ In fact, as high as $75-90 \%$ of patients have been reported to not survive beyond 2 years after having been diagnosed with purpura. ${ }^{13} 4$ Whether this association merely reflects or contributes to the final illness is unclear. $^{1}$

Second, it carries an important learning point that CF-related vasculitis, which is most often cutaneous, may become systemic. In the latter, urgent treatment is required with steroids and immunosuppressive drugs. ${ }^{5}$ It is vital to perform a thorough investigation to identify early systemic involvement and at regular intervals during the course of illness.

\section{CASE PRESENTATION}

The patient was a 22-year-old man diagnosed with CF since the age of 5 . He presented with shortness of breath and increased sputum production, along with worsening purpuric rash on his lower limbs (figure 1). He had noticed the rash at the onset of his infective exacerbation of CF (IECF) on this occasion. This was the third occurrence of his vasculitic rash. The first episode occurred several months ago when he did have worsening of his pulmonary symptoms, and the second episode occurred 6 weeks ago in isolation in which the rash remitted spontaneously after 1 week.

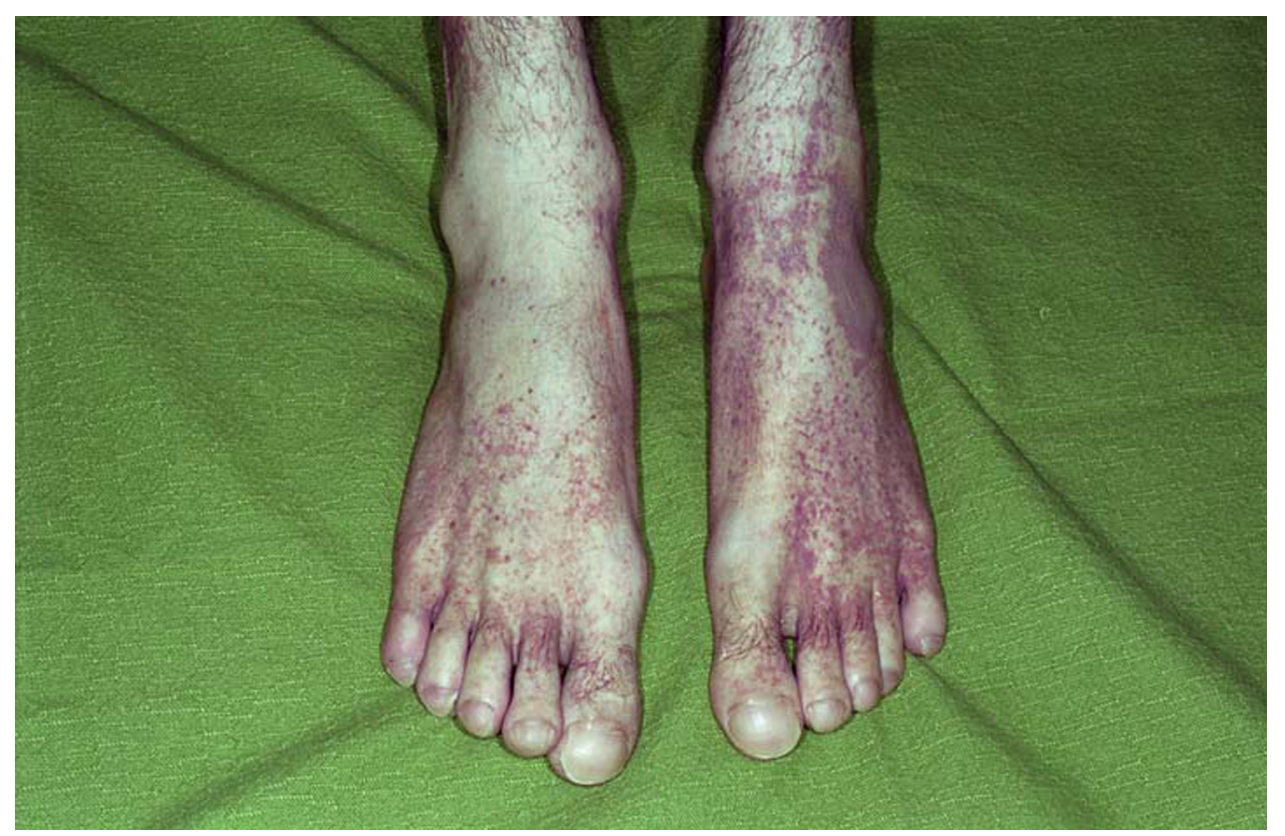

Figure 1 Palpable, purpuric, vasculitic rash on the dorsa of the feet, ankles and tibial surfaces, with marked clubbing of all toenails. 


\section{BMJ Case Reports}

\section{INVESTIGATIONS}

Investigations performed showed evidence of mild IECF. There was no coagulopathy or systemic involvement. Urinalysis was unremarkable and autoimmune screen only showed positive antinuclear antibody 1:160. Antistreptolysin $O$ titre, hepatitis B virus and hepatitis $C$ virus were negative. Protein and immunoglobulin electrophoresis were normal. Skin biopsy was not performed.

\section{OUTCOME AND FOLLOW-UP}

Initial treatment of intravenous antibiotics was given on admission. Following thorough investigations, immunosuppression with azathioprine was administered shortly after. The patient responded well and was discharged home 2 weeks later. Over the next several months, he had increasing frequency of IECF, sometimes occurring with cutaneous vasculitis and rarely the latter occurring in isolation. Because of pulmonary complications, the patient died within 18 months of the onset of the initial rash.

\section{DISCUSSION}

Vasculitis is a recognised but unusual complication of CF occurring in approximately $2-3 \%$ of patients. ${ }^{2}{ }^{6-10}$ The majority of cases in the current literature, which mainly comprises of case reports and case series, occur in patients over 20 years of age. ${ }^{2}$ The case we have presented is classic in that of the age group (over 20), the distribution of the rash (distal lower limbs) and the prognosis (often poor). Diagnosis is usually made clinically, however, if a skin biopsy is performed, histology will show features consistent with leukocystoclastic vasculitis. ${ }^{6}$

The underlying aetiology of CF-related vasculitis is not known. A multifactorial cause has been suggested, involving associations with bacterial antigens, hypergammaglobulinaemia, immune complexes and drug therapy. ${ }^{5}$ While it has been reported that there is no clear association between infective exacerbations or sputum microbiology and vasculitis, ${ }^{1}$ it has also been postulated that autoantibodies against bactericidal/permeability-increasing protein antibodies (BPI) might play a role. ${ }^{2}$ These are found frequently in patients with CF with vasculitis and levels appear to correlate with pseudomonal load, reduction in lung function and the presence of vascultis. ${ }^{2}{ }^{10}$ BPI expresses a protective activity against lipopolysaccharide-induced injury on vascular endothelial cells. ${ }^{211}$ Thus, if anti-BPI antibodies interfere with this function, it is thought they may facilitate vasculitic inflammation. ${ }^{2}$

A significant proportion of patients with CF-related vasculitis also report arthralgia, and systemic involvement is possible. In the latter, urgent treatment is required with steroids and immunosuppressive drugs. ${ }^{5}$

\section{Learning points}

- Vasculitis in CF is usually cutaneous.

- CF-related vasculitis is associated with more advanced disease $^{1}$ and a poor prognosis. ${ }^{2}$

- Complete and thorough investigation is essential for early detection of systemic vasculitis and at regular intervals during the course of an unremitting rash.

Acknowledgements The authors would like to thank Professor Margaret Hodson and Dr Gyi for their guidance in the Cystic Fibrosis Department at the Royal Brompton Hospital, London.

\section{Competing interests None.}

Patient consent Obtained.

\section{REFERENCES}

1. Kastelik JA, Mulrennan SA, Morice AH. Vasculitis in Cystic Fibrosis http://www.cysticfibrosismedicine.com/htmldocs/CFText/vasculitis.htm (Accessed 1 April 2010)

2. Elkin S. Arthritis, vasculitis and bone disease. Prog Respir Res Basel, Karger 2006;34:270-7.

3. Nielsen HE, Lundh S, Jacobsen SV, et al. Hypergammaglobulinemic purpura in cystic fibrosis. Acta Paediatr Scand 1978;67:443-7.

4. Phillips BM, David TJ. Pathogenesis and management of arthropathy in cystic fibrosis. J R Soc Med 1986;79(Suppl 12):44-50.

5. Hodson ME. Vasculitis and arthropathy in cystic fibrosis. J $R$ Soc Med 1992;85(Suppl 19):38-40.

6. Finnegan MJ, Hinchcliffe J, Russell-Jones D, et al. Vasculitis complicating cystic fibrosis. Q J Med 1989;72:609-21.

7. Bourke S, Rooney M, Fitzgerald M, et al. Episodic arthropathy in adult cystic fibrosis. Q J Med 1987;64:651-9.

8. Schidlow DV, Panitch HB, Zaeri N, et al. Purpuric rashes in cystic fibrosis. Am J Dis Child 1989;143:1030-2.

9. Schidlow DV, Goldsmith DP, Palmer J, et al. Arthritis in cystic fibrosis. Arch Dis Child 1984;59:377-9.

10. Zhao MH, Jayne DR, Ardiles LG, et al. Autoantibodies against bactericidal/ permeability-increasing protein in patients with cystic fibrosis. OJM 1996;89:259-65

11. Arditi M, Zhou J, Huang SH, et al. Bactericidal/permeability-increasing protein protects vascular endothelial cells from lipopolysaccharide-induced activation and injury. Infect Immun 1994;62:3930-6.

\footnotetext{
This pdf has been created automatically from the final edited text and images.

Copyright 2010 BMJ Publishing Group. All rights reserved. For permission to reuse any of this content visit

http://group.bmj.com/group/rights-licensing/permissions.

BMJ Case Report Fellows may re-use this article for personal use and teaching without any further permission.

Please cite this article as follows (you will need to access the article online to obtain the date of publication)

Wujanto L, Ross C. Recurrent vasculitis in cystic fibrosis. BMJ Case Reports 2010;10.1136/bcr.03.2010.2834, date of publication

Become a Fellow of BMJ Case Reports today and you can:

- Submit as many cases as you like

- Enjoy fast sympathetic peer review and rapid publication of accepted articles

- Access all the published articles

- Re-use any of the published material for personal use and teaching without further permission

For information on Institutional Fellowships contact consortiasales@bmjgroup.com

Visit casereports.bmj.com for more articles like this and to become a Fellow
} 